amount of data; other genes are less accurately placed. Still others, not so well determined, have been omitted from this diagram.

The localisation of the genes has been calculated from numerical data independently of any assumption as to how crossing-over takes place in the animal. Perhaps it might be safer to let the matter rest on the genetic evidence alone in the present uncertain frame of mind of most cytologists concerning the conjugation of the chromosomes at maturation; but there are at least certain facts admitted by a number of cytologists concerning the maturation of eggs and sperm that seem to fall into line with the simple mechanism that the genetic evidence for crossing-over calls for. This evidence may next be considered.

(To be continued.)

\title{
Science in Poland.
}

$\mathrm{D}$ URING the past seven years Poland has suffered all the miseries of war. Amid the desolation in which the country was plunged, the votaries of science did their best, until I9I9, to uphold the interests of study and education against inimical and contending Governments ; since the Polish State was resuscitated they have been engaged in laying the foundation of the work of the future. In I9I4 only two Polish universities (Cracow, Lwów) were in existence; in I922 five large State-endowed universities are actively

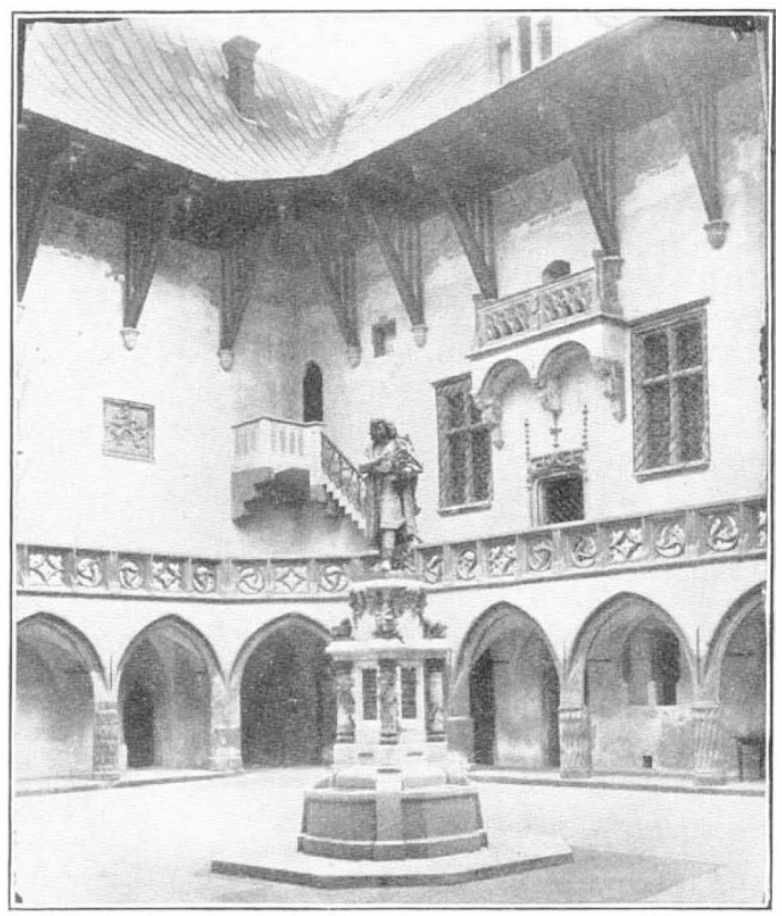

FIG. 1.-Interior Court of the Library of the Jagellonian University, Cracow, with the statue of Copernicus.

at work; the University of Warsaw was started in r9r5, those of Poznan and Wilno in r9r9. Centres of technical teaching and research are springing up; in Warsaw and Lwów important colleges of mechanical and electrical engineering, of applied chemistry, of architecture, etc., are well attended, and in I9r9 a High School of Mines was established in Cracow. These institutions are sufficiently equipped with appliances required for practical teaching.

Agricultural science also receives a good deal of attention; in addition to faculties or other schools of university rank existing in Cracow, Warsaw, Lwów, and Poznan, a National Institute of Agricultural NO. 273I, VOL. 1O9]
Research was founded in Pulawy in 1917. This institute is under the direction of Profs. Godlewski and Marchlewski, and shows a remarkable completeness of arrangement. For the study of the mineral resources of Poland, a National Geological Institute was created in I920 in Warsaw, under Prof. Morozewicz; a branch institution in Cracow, under Dr. Nowak, has for its object the investigation of oil-bearing regions. An Epidemiological Institute, a Central Meteorological Office, and a Natural History Museum have been constituted; but within the brief compass of an article it is impossible to do more than refer simply to the fact of their inauguration.

At the head of Polish educational institutions stands the Jagellonian University of Cracow, founded by Casimir the Great, King of Poland, in I364. In 1400 the university was restored and enlarged by King Ladislas Jagello, who thus complied with the last wish of his universally honoured and beloved wife, Queen Jadwiga. At the end of the fifteenth century the university was at the height of its influence and fame; there was probably no contemporary school in Europe where mathematics and astronomy were prosecuted with more zeal and success. An undergraduate matriculated in the university in I49I who was to transmit his name to the remotest posterity. At that time Wojciech Brudzewski (Albertus de Brudzewo) had attained a wide and established reputation as an astronomer, and it was probably by him that young Copernicus was taught to employ his genius.

In the seventeenth and eighteenth centuries the university suffered much from the insecurity of the times, and for many years was on the decline. A new epoch began about 1870 ; an impulse was given to study, and research, although hampered by financial embarrassments, had greater importance assigned to it than at any previous period. Among the mathematicians of that period are Mertens, Baraniecki, and Zrawski ; Rudzki did creditable work in geophysics, especially seismology ; Zygmunt Wróblewski and Karol Olszewski, by their activity in the domain of low temperature research, achieved success that shed lustre on the Cracow laboratories; Witkowski, by the pains he took to ensure accuracy, paved the way for much subsequent thermodynamical investigation; Smoluchowski (whose untimely death, in $\mathrm{Ig} 7$, was a matter of universal regret) accomplished brilliant work, largely influencing progress towards a kinetic theory of matter. Within the precincts of the Jagellonian University, Janczewski, E. Godlewski, Sen., Rostafinski, Raciborski, Rothert, Kulczynski, Prazmowski, Wierzejski, Jentys, Adametz, Majer, Kopernicki, and TalkeHryncewicz - names well known to students of 
botanical, zoological, or anthropological sciencewere engaged in teaching and research. The medical faculty will always be associated with the names of Dietl, Teichmann, Cybulski, Browicz, Jordan, Pieniazek, Korczvnski, Jaworski, Mikulicz, Rvdygier, Wicherkiewicz, and others.

The Jagellonian University always consisted, and now consists, of four faculties. The faculty of theology has nine professors; the faculty of jurisprudence has sixteen professors and four lecturers ; while the faculty of medicine includes twenty-six professorial chairs and thirteen lectureships. The philosophical faculty embraces literature and philology, history and philosophy, mathematical, physical, and natural science; in connection with this faculty there is a college of agriculture, a department of pharmacy, and a teachers' training school. No less than sixty-eight professors and twenty-two lecturers are engaged in the work of this faculty. The total number of matriculated students during the session $192 \mathrm{x}-22$ is $463 \mathrm{I}$.

Space will permit only of a reference to the library of the university (Biblioteka Jagiellonska), renowned for the precious MSS. it contains.

L. N.

\section{Current Topics and Events.}

THE national manifestation of rejoicing on the occasion of the marriage of H.R.H. Princess Mary to Viscount Lascelles on Tuesday, February 28, is a sign of the secure place which the Royal Family occupies in the hearts of the British people and also, we hope and believe, a token of national unity. In common with all classes of the community, workers in scientific fields marked the occasion with affectionate interest and shared with much satisfaction in the chorus of good wishes by which the nation expressed itself in perfect harmony with a happy event.

THE following fifteen candidates have been selected by the Council of the Royal Society to be recommended for election into the Society:-Prof. T. H. Bryce, Mr. C. G. Darwin, Dr. C. G. Douglas, Dr. S. R. Douglas, Prof. A. J. Ewart, Dr. A. Hutchinson, Dr. F. W. Lanchester, Mr. J. Mercer, Prof. S. R. Milner, Prof. M. S. Pembrey, Prof. F. Lee Pyman, Prof. G. A. Schott, Dr. N. V. Sidgwick, Mr. D. M. S. Watson, Sir Alfred Yarrow, Bart.

THE Report of the Aeronautical Research Committee on the causes which led to the loss of the airship R. 38 was issued by the Air Ministry on February 23. The Committee has come to a number of clear findings and has summarised them at the end of its report; it has concluded, from an examination of the evidence available, that the airship broke in two as a result of defects in design, but that the loss of life was to be attributed largely to a subsequent fire. It appears that the only calculations made by the designers were of the type used in general engineering and had little special reference to airships. In addition, no account was taken of the aerodynamic forces which an airship might reasonably experience in normal usage. Information as to the importance of the air forces is said to have existed from experiments on models of airships in the wind tunnels, but the warning was not acted upon even to the extent of referring the problem to the Aeronautical Research Committee. Shortly expressed, the result of the enquiry shows the marked deficiency of rule-of-thumb as compared with scientific methods as an instrument of progress. The accounts of the accident in America to the semi-rigid airship, Roma, further point the moral. The obvious fundamental fact in engineering design is that the details of a structure should depend on the forces it has to withstand. In an airship the bending arises in part from the distributed weights and in part on aerodynamic loading, the former being independent of the speed of flight and the latter to its square. Hence an airship moving at 30 knots may have the stresses due to weight and buoyancy twice those due to aerodynamic causes, whilst at a speed of 60 knots the proportions are exactly reversed. The accident to R. 38 appears to have occurred when the air loading was at least five times that provided for by the designers on the basis of weight alone. There is great difficulty in introducing improvements into aircraft with the present official organisation, and it is to be hoped that the report will receive due consideration from the point of view that it is desirable to provide for scientific progress rather than for a process of trial and error on a large scale and at great expense in life and money.

ThE third and final Report of the Committee on National Expenditure (Cmd. I589, price $4^{s}$.), issued on February 24, deals, among other services, with the British Museum, National Gallery, National Portrait Gallery, Wallace Collection, London Museum, Imperial War Museum, Geological Museum, and National Galleries (Scotland). The Estimates for I92 I-22 and the Provisional Estimates for 1922-23 are respectively $£ 506,77 \mathrm{x}$ and $£_{405}, 864$. Over 80 per cent. of the Estimate is in respect of the cost of personnel. The Committee thinks that further economies might be produced by a close investigation into the size of the warding staff, especially in the case of the British Museum and the Natural History Museum. It recommends that there should be four paying days a week for all National Museums and Art Galleries without distinction. The Committee is of opinion that the net sum of $t_{4} 0_{5}, 864$, which is asked for in the Provisional Estimates for $1922-23$, should be reduced to $£ 392,264$, a saving of $£=3,600$. With regard to the grants for scientific investigation, amounting in all to $£ 200,423$, it is recommended that the grant to the Medical Research Council-Er30,00o-should be as proposed by the Treasury. As regards the smaller grants, the Committee says: "We are averse from an arbitrary and uniform reduction on a percentage basis on the ground that the saving to the Exchequer would be small compared with the detriment which would be caused to the activities of the learned and scientific world and the discouragement which would be given to private subscriptions and donations if the Exchequer grants were reduced. We therefore recom- 